\title{
The Level of 7- and 8-Years Old Children Understanding of the Place Value Concept
}

\author{
Halil Önal, (Dr.) \\ Burdur Mehmet Akif Ersoy University, Turkey \\ Emel Cilingir Altiner, (Dr.) \\ Çukurova University, Turkey
}

Submitted: 29 June 2021

Accepted: 21 October 2021

Published: 31 December 2021
Copyright 2021 Author(s)

Under Creative Commons BY-NC-ND

4.0 OPEN ACCES

\section{Abstract}

Place value concept that learns especially in primary school ages is also the basis of many issues students will encounter throughout their learning lives. This research aims to developmentally determine understanding of the place value concept in early childhood. The model of research is a case study from qualitative research methods. The study group consists of 171 children (84 at the age of 7 and 87 at the age of 8) who study in three different public schools in January, in the 2020-2021 academic year in Ankara, Turkey, selected by criteria sampling from purposeful sampling methods. As a data collection tool, "place value worksheets" consisting of 25 questions developed by researchers were used. Data was collected online by classroom teachers through "EBA". The content analysis method was used in the analysis of the data. Looking at the research results, it was observed that children gave meaning to the place value concept in seven categories. It was seen that seven years olds reached the lowest correct answer rate in the code "the ability to express the number whose resolution is given in terms of ones" in the category of "the ability to resolve". It was concluded that "the ability to write numbers between two numbers" code in "the ability to compare" category has the lowest correct response rate for eight years old children. Lower levels of seven years old student's understanding of the place value concept suggest that students' readiness levels are not sufficient at this age.

Keywords: Place value, developmental understanding, level of 7 years old, level of 8 years old, early childhood 


\section{Introduction}

The impact of the school on mathematics education is major and differs from other subject areas. Children often interact with the social environment or their families outside of school on topics such as discussing current issues, exploring nature, or reading books. For many children, the important thing about mathematics is what is learned in school (Van de Walle et al., 2014, p.9). For many people, learning and remembering mathematics and applying the rules of mathematics are difficult (Cooke, 2007, p.1). Learning mathematics requires children to establish and reconstruct mathematical relationships in their own minds. Children need direct and concrete interaction with mathematical ideas. Continuous interaction between the child's mind and concrete experiences in the real world is seen as necessary (Burns, 2007, p.27). At an early age, children learn abstract mathematical relationships by interacting with concrete objects and their peers. These children reconstruct mathematical knowledge by structuring it through studying a model suitable for knowledge, but cannot directly understand abstract relationships (Olkun \& Toluk Uçar, 2012, p.31).

In elementary school mathematics, it is very important to firmly establish conceptual foundations in every subject (Altun, 2012, p.60). Since the place value concept is one of the most abstract concepts related to numbers, the teaching of it also extends for a long time (Dinç Artut \& Tarım, 2006). A complete understanding of the place value is important for a child's development if it considered its continuation as decimal number notation during primary and secondary school. The most critical period in this development for the natural number concept is the period from pre-school to third grade (Van de Walle et al., 2014, p.187). According to Olkun and Toluk Uçar (2012), the solid foundations of the place value concept and the decimal number system should be laid from the beginning of the second grade (7 years). In this process, i.e., the relations between the representation of a number with concrete models, the reading and writing of the number should be given attention.

Place value refers to the value of a digit in the number. The place value is the basis of the Hindu-Arabic number system, which allows us to show numbers using ten digits $(0,1,2,3,4,5,6,7,8,9)$ (Baykul, 2005; Chapin \& Johnson, 2006; Mooney, Briggs, Fletcher, Hansen \& McCulloch, 2009; Cotton, 2010; Hansen, 2014; Haylock \& Cockburn, 2014; Van de Walle et al., 2014). The value of each number is determined by its digit place (from right to left), the first digit on the right indicates the ones, the second digit shows tens, the next shows hundreds, and the other digits show increasing powers of 10. The most important contribution to the value represented by a number is coming from its place on the digit, and this is called the place value principle. Nine (9) in the number 900 represents 10 times much more value than 9 in the 
number 90. A well-understanding place value concept is the basis for operations with numbers and accurate calculation (Haylock \& Cockburn, 2014 , p. 167). The child should understand the importance of the position of a number and be able to specify what each number means in a multi-digit number. This, in turn, can be explained by dividing the number by the digits of hundreds, tens, and ones (Mooney et al., 2009, p. 126).

The place value concept is one of the most important challenges that children face about the number (Engelhardt, 1977; Brown \& Burton, 1978; Ross, 1986; Kamii, 1988; Thompson, 2002; Cockburn, 2005; Dinç Artut \& Tarım, 2006; Olkun \& Toluk Uçar, 2012; Rogers, 2014; Hansen, 2014; Haylock \& Cockburn, 2014; Van de Walle et al., 2014). Children encounter the place value for the first time when they write the number ten with the digits as 10. The words they have encountered so far such as twenty, fifty, and hundred make them think that these numbers only mean being "more" than their true value. Students should be able to understand that 10 is both a unit and consists of 10 one (Olkun \& Toluk Uçar, 2012, p.83). Understanding the place value requires the integration of procedural knowledge of how groups are recorded in our place value scheme, how numbers are written and how they are spelled, with decimal grouping (decimal system concept), which are new and difficult concepts to imagine (Van de Walle et al., 2014, p.188).

When the literature regarding the place value concept is examined, it is seen that the common focuses of the studies abroad are used to determine the level of students' understanding of the place value, the teaching process of the place value concept taking a long time, and the difficulties and mistakes experienced in teaching the place value (Engelhardt, 1977; Brown \& Burton, 1978; Kamii, 1986; Ross, 1986; Kamii \& Joseph, 1988; Fuson, 1990; Fuson \& Briars, 1990; Lewis, 1993; Sharma, 1993; Jones et al., 1996; Thompson, 2000; Thompson \& Bramald, 2002; Nataraj \& Thomas, 2007; Cayton \& Brizuela, 2007; Cuffol, 2009; Major, 2012; Rogers, 2014; Byerge at al., 2014). Furthermore, there are few studies conducted in Turkey (Dinç Artut \& Tarım, 2006, Albayrak et al., 2006; Kaplan, 2008; Arslan et al., 2011; Tosun, 2011; Dinç Artut \& Tarım, 2013; Paydar, 2018; Mutlu \& Sarı, 2018). Since mathematical concepts are abstract, they cause misunderstandings especially from the point of view of children aged 7 and 8 years who are in the period of concrete operations. Incorrect information learned about concepts during these periods negatively affects student success in subsequent periods. Therefore, children may develop negative attitudes and behaviors about mathematics and anxiety may occur about mathematics Therefore, mathematics becomes a lesson that is not liked by children. In mathematics, the teaching of the place value concept in the field of learning numbers and operations begins from the second grade of primary school (7-year-old). The previously learned subject is a prerequisite for other subjects. Especially in primary school ages, incorrect and incomplete information can make teaching other subjects difficult or cause 
them to not be fully learned. However, the place value concept is also the basis of many issues that students will encounter throughout their learning lives.

For this reason, it is important to determine the students' understanding level of the place value concept during primary school ages. To shed light on future studies within the framework of dimensions that are considered important in understanding the place value, it is important to reveal the current situation of children. However, in this case, it is believed that proposals can be made for future studies and contribute to education. This research aims to developmentally determine the level of 7- and 8-years-old children's understanding of the place value concept. Answers to the following questions will be sought in line with the stated purpose:

- What is the level of 7-years-old (second grade level) children's understanding of the place value concept?

- What is the level of 8-years-old (third grade level) children's understanding of the place value concept?

\section{Method}

\section{Participants}

The study group of the research consists of 84 students at the second grade level (7 years old) (48f, 36m) of primary school and 87 students at the third grade level of primary school ( 8 years old) (45f, 43m). A total of 171 students who continue their education in three different public schools in January 2020-2021 academic year in Ankara, Turkey, were selected. They were selected by criteria sampling from purposeful sampling methods. Criterion sampling is the study of people, events, objects, or situations that meet a predetermined set of criteria (Baltac1, 2018). It was accepted as a criterion because at the stage of selection, the students constituting the study group had equal levels of mathematical success during the selection phase, and they came from the same socio-economic and socio-cultural conditions.

\section{Instruments}

In this study, the "place value worksheet" developed by the researchers was used as a data collection tool. A worksheet consisting of 25 items was developed to measure the place value concept by examining the primary school mathematics program, teacher's guide books, student textbooks, auxiliary textbooks, and related literature. Lawshe analysis was performed by taking expert opinions from 2 mathematics education experts and 3 elementary school teachers. Thereafter, the content validity ratios (CVR) were determined based on the data obtained from experts. The CVR values of the questions were 0.6 and higher. Arrangements have been made regarding the question sentences and operations that have been requested to be corrected. The scoring of these questions is accepted as 1 (one). As a result, a pilot application was conducted on 53 students in a different school from the research group with 
the obtained 25 questions. After the feedbacks, the necessary arrangements were made and a "place value worksheet" was created.

\section{Design and Procedure}

The model of the study, which aims to determine the level of 7- and 8year-old children's understanding of the place value concept, is a case study from qualitative research methods. Qualitative research is necessary to find answers to questions that are difficult to express by traditional research methods. Qualitative research deals with how and why behavior occurs by describing how people interpret what they experience (Merriam \& Tisdell, 2015 , p.14). A case study is an approach in which the researcher collects indepth information through multiple sources of information (observation, interview, audiovisual materials, documents, and reports) about real life, a current limited system (a situation), or multiple restricted systems over a given time, involving in-depth and longitudinal examination of the analyzed data (Creswell, 2016, p.97; Glesne, 2012, p.30).

This study took place in an education system designed by the constructivist educational approach (students are more active in the learning process, constructing the knowledge themselves) adopted since 2015 in Turkey. It is still a matter of debate in this country whether the transition to constructivist education is achieved or not.

School administrators and teachers in schools in which implementation is conducted have been informed by researchers about the study and process. In line with the provided information, classroom teachers shared the "place value worksheet" developed by the researchers over the "EBA" on the online system and asked the students to answer the questions during 2 lesson hours. Students took photos of the questions they answered and sent them to their classroom teachers. Finally, the classroom teachers provided the researchers with images of the worksheets containing the students' answers so that the data could be collected.

\section{Analysis of Data}

Data collected using the "place value worksheet" in the study was analyzed using the content analysis technique. Data analysis in qualitative research involves preparing and organizing data for analysis, then encoding data and reducing them to categories by combining codes, and finally presenting the data in figures, tables, or discussion (Creswell, 2016, p.180). Content analysis is defined as a systematic and repeatable technique in which some words of a text are summarized by smaller categories of content with certain rules-based encodings (Büyüköztürk et al., 2017, p.240). Coding and analyzing data is an analytical stage. Organizing the coding hierarchically is part of the analysis process (Gibbs, 2007; Glesne, 2012). 
The most useful method for increasing reliability in qualitative research is member control (Gibbs, 2007; McMillan, 2000; Glesne, 2012). In this study, a second researcher encoded the data and reviewed the encodings to ensure the reliability of the encoding while conducting the content analysis. The data was re-encoded by the second researcher and the encoder consistency value was determined as 94.74. As a result of the analysis, codes and categories were created for the place value concept. Hence, the analyzed data was digitized and turned into tables.

\section{Results}

In the study, students' responses to worksheets were examined and their level of understanding of the place value concept was tried to be determined. Therefore, seven categories were reached. These categories are the ability to group, the ability to express places with shapes, the ability to position numbers, the ability to rename digits, the ability to resolve, the ability to compare, and operations. According to the answers given by children aged 7 , the codes, frequencies, and types of answers related to each category are given in Table 1.

Table 1. The Levels of 7-year-old Children's Understanding of the Place Value Concept

Types of Answers

Correct Incorrect Unanswered

$\begin{array}{lllll}\text { f } & \% & \text { f } & \% & \text { f }\end{array}$

\section{The Ability to Group}

The ability to count objects

$\begin{array}{lll}74 & 88.10 \quad 8\end{array}$

$9.52 \quad 2$

2.38

The ability to group objects into

$53 \quad 63.10$

27

$32.14 \quad 4$

4.76

ones

$\begin{array}{lllllll}\text { The ability to group objects into } & 48 & 57.14 & 30 & 35.71 & 6 & 7.14\end{array}$ tens

\section{The Ability to Express Places with Shapes}

$\begin{array}{lllllll}\text { The ability to write the number } & 69 & 82.14 & 11 & 13.10 & 4 & 4.76\end{array}$

indicated by decimal base blocks

$\begin{array}{llllllll}\text { The ability to show a number } & 67 & 79.76 & 14 & 16.67 & 3 & 3.57\end{array}$

with decimal base blocks 
$\begin{array}{lllllll}\text { The ability to show the location } & 59 & 70.24 & 21 & 25.00 & 4 & 4.76\end{array}$ of a number on a number line

\section{The Ability to Position Numbers}

The ability to place numbers 74

$\begin{array}{llll}88.10 & 9 & 10.71 & 1\end{array}$

in the appropriate place

The ability to write the 76

90.48

6

7.14

number using the place value

\section{The Ability to Rename Digits}

The ability to write the 78

$92.86 \quad 6$

7.14

0

0.00

pronunciation of a number

The ability to write the 78

92.86

5

$5.95 \quad 1$

1.19

number according to the

pronunciation

\section{The Ability to Resolve}

The ability to resolve numbers 68

$80.95 \quad 13$

$15.48 \quad 3$

3.57

The ability to write the 73

$86.90 \quad 8$

$9.52 \quad 3$

number whose resolution is

given

The ability to express the 46

$54.76 \quad 34$

$40.48 \quad 4$

4.76

number in terms of ones

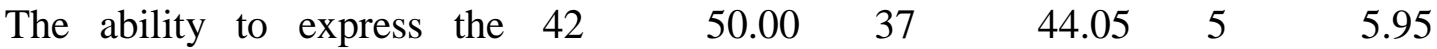

number whose resolution is

given in terms of ones

\section{The Ability to Compare}

The ability to write the numbers 72

$85.71 \quad 11$

$13.10 \quad 1$

1.19

before and after a number

The ability to write numbers 51

60.71

32

$38.10 \quad 1$

between two numbers 
The ability to sort numbers

69

82.14

13

15.48

2

2.38

The ability to round numbers 61

$72.62 \quad 18$

$21.43 \quad 5$

5.95

up

\section{Operations}

The ability of addition with 68

$80.95 \quad 15$

$17.86 \quad 1$

1.19

resolved numbers

The ability of subtraction with 62

73.81

19

$22.62 \quad 3$

resolved numbers

The ability to multiply by $10 \quad 53$

63.10

28

$33.33 \quad 2$

2.38

The ability to divide by 10

59

70.24

22

$26.19 \quad 3$

3.57

When Table 1 is examined, it is seen that "the ability to count objects", which is included in "the ability to group" category regarding the level of 7year-old children's understanding of the place value concept, was made correctly by 74 students and incorrectly by 8 students. It was found to be not answered by 2 students. It was observed that "the ability to group objects into ones" was answered correctly by 53 students, incorrectly by 27 students, and unanswered by 4 students. It was found that "the ability to group objects into tens" in the category of the ability to group was answered correctly by 48 students, incorrectly by 30 students, and left unanswered by 6 students. It was seen to be the code with the lowest correct answer load value in the category of "the ability to group". Figure 1 shows the wrong answers of the students in the category of "the ability to group".

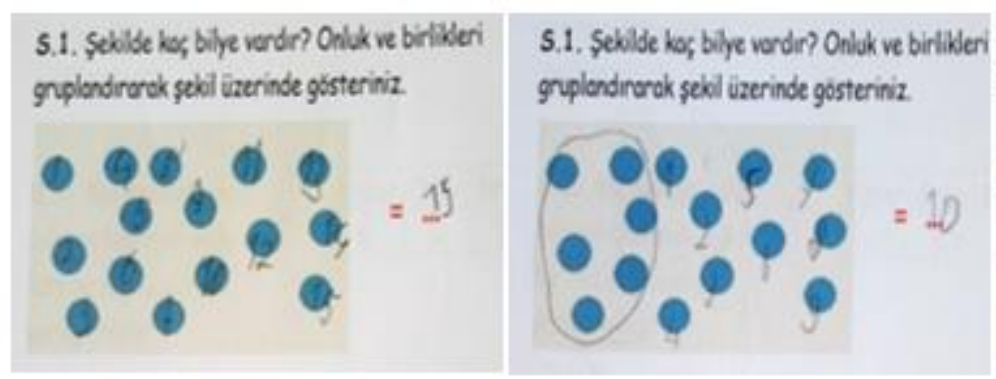

5.1. Sekilde kaç bilye vardir? Onluk ve birliklen gruplendirarak şekil üzerinde gosteriniz.

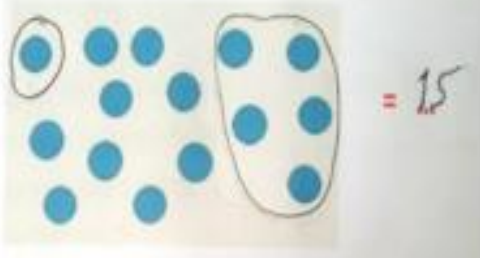

[How many marbles are there in the figure? Show groups of tens and ones]

Figure 1. Wrong Answers in the Category of the Ability to Group

In the category of "the ability to express places with shapes", "the ability to write the number indicated by decimal base blocks" was answered correctly by 69 students, wrong by 11 students, and not answered by 4 
students. "The ability to show a number with decimal base blocks" was answered correctly by 67 students, wrong by 14 students, and not answered by 3 students. It is seen that "the ability to show the location of a number on a number line" was answered correctly by 59 students, wrong by 21 students, and not answered by 4 students. Furthermore, it had the lowest load value in this category. Figure 2 shows the wrong answers of the students in the category of "the ability to express places with shapes".

5.2. Ascoğdobi onuki ve birik bloklor hangi soyy

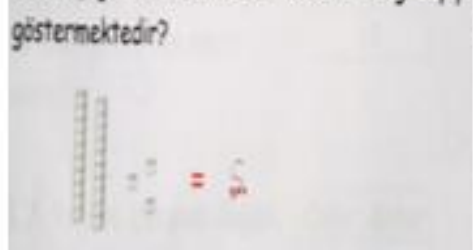

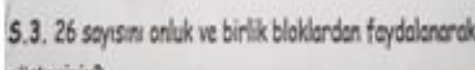
gosteriniz?

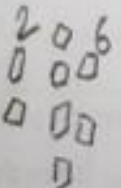

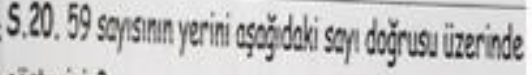
gôsteriniz?

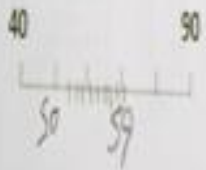

[Which number is the ten and unit blocks below?] [Show the number 26 in ten and unitblocks] [Show the number 59 on the number line below]

\section{Figure 2. Incorrect Answers in the Category "The Ability to Express Places with Shapes"}

It was found that "the ability to place numbers in the appropriate place" in the category of "the ability to position numbers" was answered correctly by 74 students, incorrectly by 9 students, and not answered by 1 student. "The ability to write the number using the place value" was answered correctly by 76 students, incorrectly by 6 students, and not answered by 2 students. In Figure 3, the wrong answers of the students in the category of "the ability to position numbers" are given.

\section{S.4. 3 sayısinı yanda bulunan Onlar Birler basamak değeri kartına doğru olarak yerleştiriniz? \\ 2. ... $\cdots$}

S.7. Yandaki basamak değeri kartında gösterilen sayıyı yaziniz?

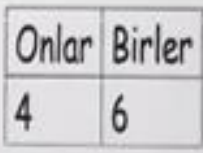
yoming?
[Insert the number 3 correctly on the place value card on the side]
[Write down the number shown on the place value card on the side]

Figure 3. Wrong Answers in the Category of the Ability to Position Numbers

It is seen that "the ability to write the pronunciation of a number" and "the ability to write the number according to the pronunciation", which are in 
the category of the ability to rename digits, were answered correctly by 78 students in equal numbers and had the same load value. "The ability to write the pronunciation of a number" was answered incorrectly by 6 students, and there were no unanswered questions. It was found that "the ability to write the number according to the pronunciation" was answered incorrectly by 5 students, and not answered by 1 student. Figure 4 shows the wrong answers of the students in the category of the ability to rename digits.

\section{S.8. 57 sayısının okunuşunu} yazınız?

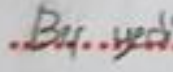

S.10. Altmış beş sayısını rakamlarla yazınız? 0.05

[Write the reading of the number 57]

[Write the number sixty five in numbers]

\section{Figure 4. Wrong Answers in the Category of the Ability to Rename Digits}

In the category of "the ability to resolve", "the ability to write the number whose resolution is given" was answered correctly by 78 students, incorrectly by 8 students, and not answered by 3 students. In addition, it had the highest correct answer load value among the codes in "the ability to resolve" category. Figure 5 shows the wrong answers of the students in the category of "the ability to resolve".

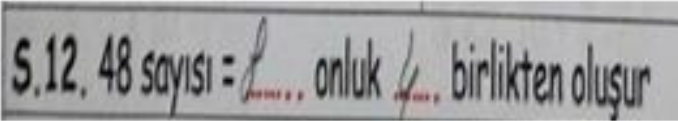

\section{S.14. 30 sayıs $ı=20$. onluk 0 . birlikten oluşur.}

[The number $48=\ldots$ tens and ... ones]

\subsection{1 onluk ve 4 billik 4 ..... eder.}

S.15. 2 onluk ve 8 birlik $=\mathcal{L}$ birlikten oluşur.

[1 tens and 4 ones $=$ ?]

Figure 5. Incorrect Answers in the Category "The Ability to Resolve"

In the category of "the ability to compare", "the ability to write numbers before and after a number" was answered correctly by 72 students, incorrectly by 11 students, and left unanswered by 1 student. Hence, it was the 
code with the highest correct load value in this category. Figure 6 contains the wrong answers of the students in the category "the ability to compare".

\subsection{6 ile 30 arasindaki sayilari yaziniz? ?....2. 8.2930}

[Write the numbers between 26 and 30 ]

\section{S.19. Aşağıdaki sayıları büyükten küçüğe sıralayınız? $4,6,46,64,66$}

[Order the numbers below in ascending order.]

\section{S.21. 37 saysis hangi onluğa daha yakindir? $35 . \ldots .$.}

S.16. 100 sayisindan önce gelen sayi kaçıır 20
5.17. 69 saysindon sonra gelen say kactir? hl

\section{Figure 6. Incorrect Answers for the Category "The Ability to Compare"}

In the category of "operations", the last category, it was observed that "the ability of addition with resolved numbers" was answered correctly by 68 students, incorrectly by 15 students, and unanswered by 1 student. It was determined to be the code with the highest correct load value in the "operations" category. Figure 7 shows the wrong answers of the students in the "operations" category.

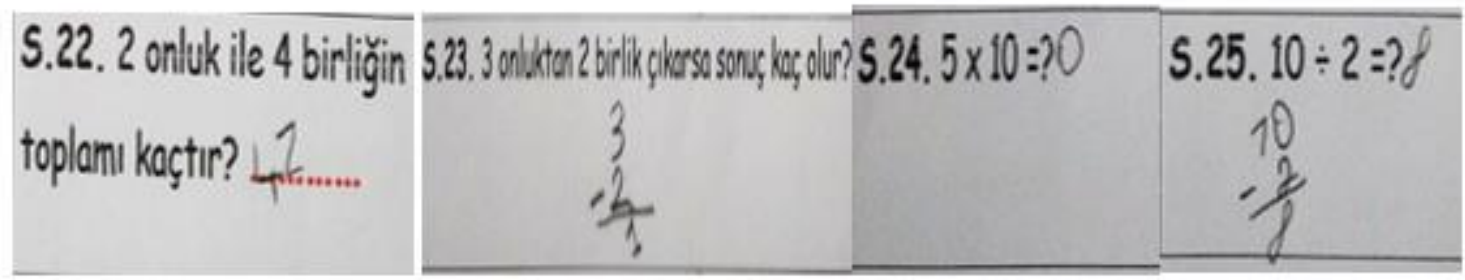

[What is the sum of 2 tens and 4 ones?] [3tens out of 2 ones, how much is it?]

Figure 7. Wrong Answers in the Operations Category 
The codes, frequencies, and types of responses related to each category obtained from the worksheet to understand the level of 8-year-old children's understanding of the place value concept are given in Table 2.

Table 2. 8-years-old Childrens' Understanding Level of the Place Value Concept

\section{Types of Answers}

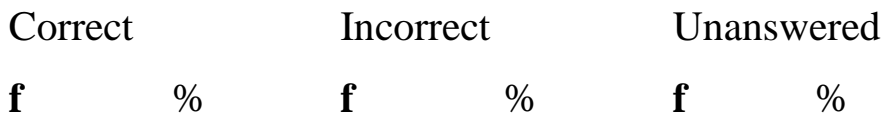

\section{The Ability to Group}

The ability to count objects 81

$\begin{array}{llllll}81 & 93.10 & 5 & 5.75 & 1 & 1.15 \\ 72 & 82.76 & 12 & 13.79 & 3 & 3.45 \\ 66 & 75.86 & 16 & 18.39 & 5 & 5.75\end{array}$

The ability to group objects 72 into ones

The ability to group objects 66 into tens

\section{The Ability to Express Places with Shapes}

The ability to write the 73

$83.91 \quad 11$

$12.64 \quad 3$

number indicated by decimal

base blocks

The ability to show a number 69

$79.31 \quad 13$

$14.94 \quad 5$

with decimal base blocks

The ability to show the 71

81.61

12

$13.79 \quad 4$

4.60

location of a number on a

number line

\section{The Ability to Position Numbers}

The ability to place numbers 78

$\begin{array}{llll}89.66 & 7 & 8.05 & 2\end{array}$

in the appropriate place

The ability to write the 79

$90.80 \quad 5$

$5.75 \quad 3$

number using the place value

\section{The Ability to Rename Digits}


$\begin{array}{llllllllll}\text { The ability to write the } & 83 & 95.40 & 3 & 3.45 & 2 & 2.30\end{array}$ pronunciation of a number

$\begin{array}{lllllll}\text { The ability to write the number } & 81 & 93.10 & 5 & 5.75 & 1 & 1.15\end{array}$ according to the pronunciation

\section{The Ability to Resolve}

$\begin{array}{lllllll}\text { The ability to resolve numbers } & 77 & 88.51 & 7 & 8.05 & 3 & 3.45\end{array}$

$\begin{array}{llllllll}\text { The ability to write the number } & 76 & 87.36 & 7 & 8.05 & 4 & 4.60\end{array}$

whose resolution is given

$\begin{array}{lllllll}\text { The ability to express the number } & 62 & 71.26 & 21 & 24.14 & 4 & 4.60\end{array}$

in terms of ones

$\begin{array}{lllllll}\text { The ability to express the number } & 59 & 67.82 & 23 & 26.44 & 5 & 5.75\end{array}$

whose resolution is given in

terms of ones

\section{The Ability to Compare}

$\begin{array}{lllllll}\text { The ability to write the numbers } & 75 & 86.21 & 9 & 10.34 & 3 & 3.45\end{array}$

before and after a number

$\begin{array}{llllllll}\text { The ability to write numbers } & 57 & 65.52 & 26 & 29.89 & 4 & 4.60\end{array}$

between two numbers

$\begin{array}{lllllll}\text { The ability to sort numbers } & 70 & 80.46 & 14 & 16.09 & 3 & 3.45\end{array}$

$\begin{array}{lllllll}\text { The ability to round numbers up } & 67 & 77.01 & 17 & 19.54 & 3 & 3.45\end{array}$

\section{Operations}

$\begin{array}{lllllllll}\text { The ability of addition with } & 76 & 87.36 & 9 & 10.34 & 2 & 2.30\end{array}$ resolved numbers

$\begin{array}{lllllll}\text { The ability of subtraction with } & 73 & 83.91 & 12 & 13.79 & 2 & 2.30\end{array}$ resolved numbers

$\begin{array}{lllllll}\text { The ability to multiply by } 10 & 68 & 78.16 & 15 & 17.24 & 4 & 4.60\end{array}$

$\begin{array}{lllllll}\text { The ability to divide by } 10 & 71 & 81.61 & 13 & 14.94 & 3 & 3.45\end{array}$


When the level of 8-year-old childrens' understanding of the place value concept was examined through Table 2, as demonstrated here, "the ability to count objects" in the category of "the ability to group" was answered correctly by 81 students, incorrectly by 5 students, and not answered by 1 student. "The ability to group objects into ones" was answered correctly by 72 students, incorrectly by 12 students, and not answered by 3 students. It was observed that "the ability to group objects into tens" was answered correctly by 66 students, incorrectly by 16 students, and left unanswered by 5 students. In the category of "the ability to group", it was determined that "the ability to count objects" code has the highest correct response load value, while "the ability to group objects into tens" has the lowest correct response load value. Figure 8 shows the wrong answers of the students in the category of "the ability to group".

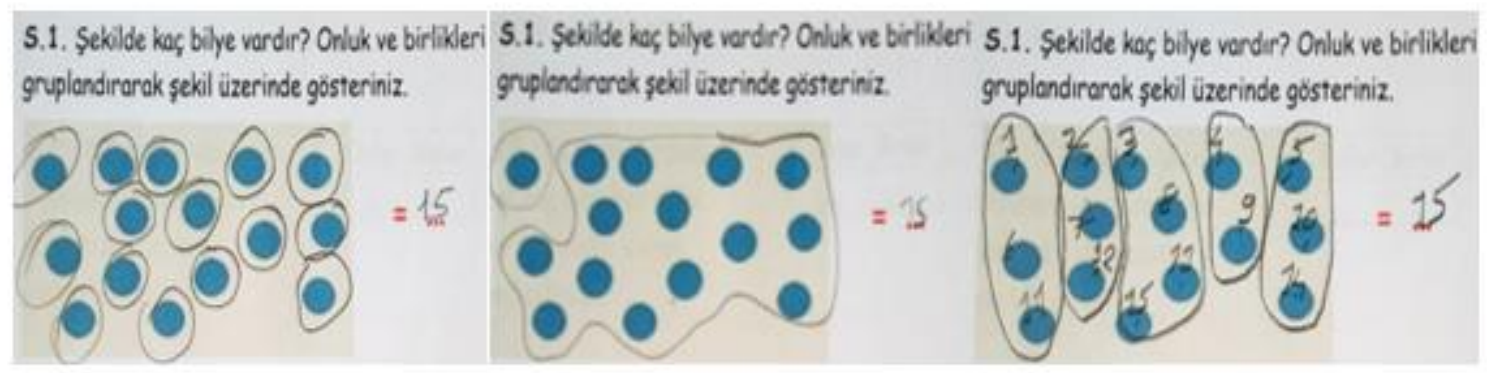

[How many marbles are there in the figure? Show groups of tens and ones.]

\section{Figure 8. Wrong Answers in the Category of the Ability to Group}

"The ability to write the number indicated by decimal base blocks" in the category of the ability to express places with shapes was answered correctly by 73 students, wrong by 11 students, and not answered by 3 students. "The ability to show a number with decimal base blocks" was answered correctly by 69 students, wrong by 13 students, and not answered by 5 students. It was found that "the ability to show the location of a number on a number line" was answered correctly by 71 students, incorrectly by 12 students, and left unanswered by 4 students. When the codes in this category are examined, it is seen that "the ability to write the number indicated by decimal base blocks" has the highest correct answer load value, while "the ability to show a number with decimal base blocks" has the lowest correct answer load value. Figure 9 shows the wrong answers of the students in the category of the ability to express places with shapes. 


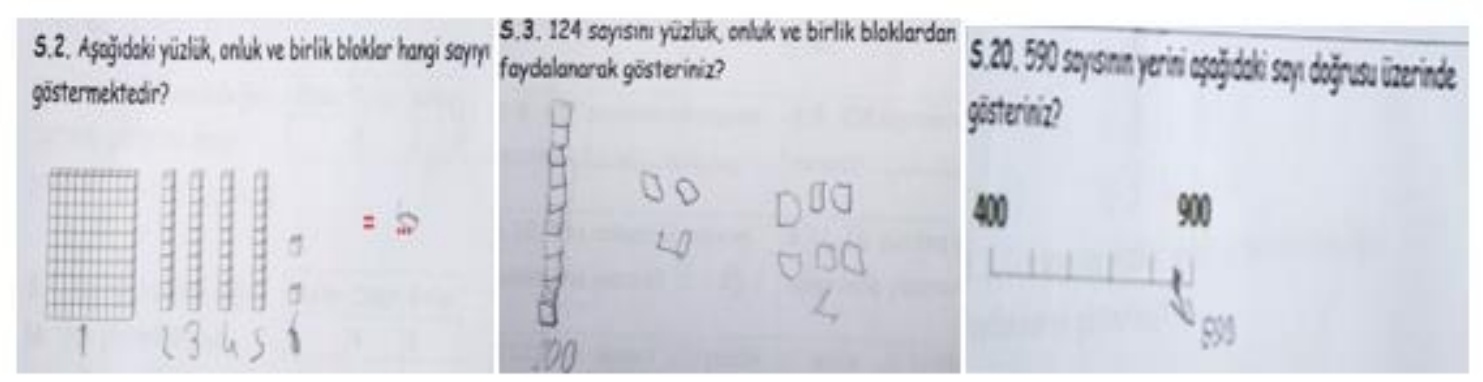

[Which awmber is the ten and uait blocks below?] [Show the number 124 in ten and uait blocks.] [Show the number 590 on the number line beiow.]

\section{Figure 9. Wrong Answers in the Category "The Ability to Express Places with Shapes"}

"The ability to place numbers in the appropriate place" in the category of the ability to position numbers was answered correctly by 78 students, incorrectly by 7 students, and not answered by 2 students. It was determined that "the ability to write the number using the place value" was answered correctly by 79 students, incorrectly by 5 students, and not answered by 2 students. "The ability to write the number using the place value" in this category has a higher correct answer load than the code "the ability to place numbers in the appropriate place". In Figure 10, the wrong answers of students in the category of the ability to position numbers are given.

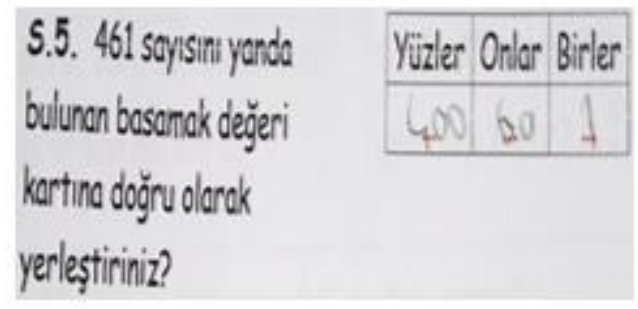

[Insert the number 461 correctly on the piace vaiue card on the side.]

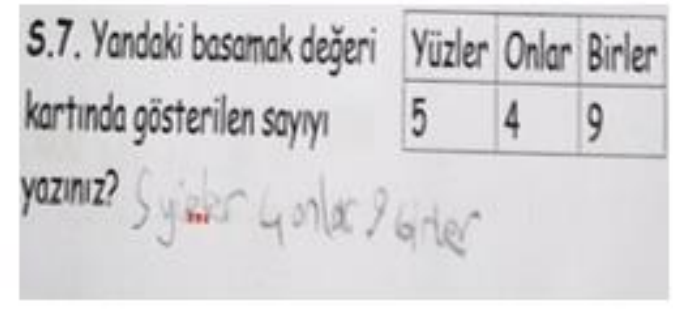

[Write down the number shown on the place value card on the side]

\section{Figure 10. Wrong Answers in the Category of "The Ability to Position Numbers"}

"The ability to write the pronunciation of a number" in the category of the ability to rename digits was answered correctly by 83 students, incorrectly by 3 students, and not answered by 3 students. "The ability to write the number according to the pronunciation" was answered correctly by 81 students, incorrectly by 5 students, and not answered by 2 students. "The ability to write the pronunciation of a number", which is in the category of the ability to rename digits, has the highest correct answer load in determining the level of 8-year-old childrens' understanding of the place value concept. Figure 
11 shows the wrong answers of the students in the category of the ability to rename digits.

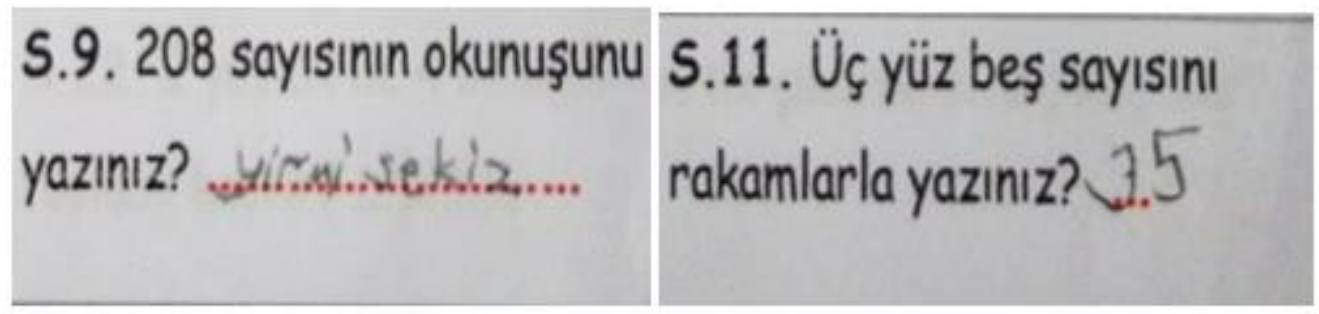

[Write the reading of the number 208.]

[Write the nuomber thres hundred five in nombers.]

\section{Figure 11. Wrong Answers in the Category of the Ability to Rename Digits}

It was found that "the ability to resolve numbers" in the category "the ability to resolve" was answered correctly by 77 students, incorrectly by 7 students, and not answered by 3 students. In addition, it was found to have the highest correct answer load value among the codes in the category "the ability to resolve". Figure 12 shows the wrong answers of the students in the category "the ability to resolve".

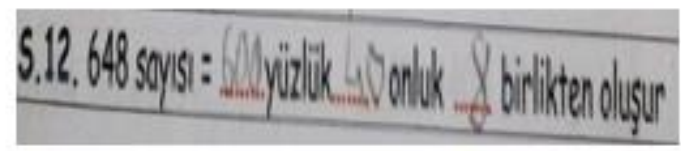

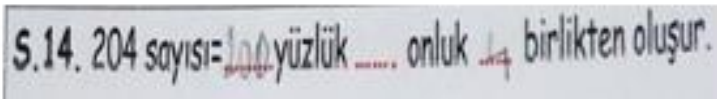

[The number $684=\ldots$ hundreds ... tens and ... ones]

S.13. 5 yüzlük, 1 onluk ve 4 birlik 54 .1. eder. S.15. 3 yüzlïk, 2 onlukve 8 birlik: \& birlikten oluşur.

[5 hundreds I tens and 4 ones $=$ ?]

Figure 12. Incorrect Answers in the Category "The Ability to Resolve"

"The ability to write numbers before and after a number" in the category "the ability to compare" was answered correctly by 75 students, incorrectly by 9 students, and left unanswered by 3 students. It is the code with the highest correct answer load value in the category "the ability to compare". Figure 13 contains the wrong answers of the students in the category "the ability to compare". 
S.18. 426 ile 430 arasındaki sayilari yaziniz? .426 4.427 4.28 6

[Write the numbers between 426 and 430 ]

S.19. Aşağıdaki sayıları büyükten küçüğe sıralayınız?

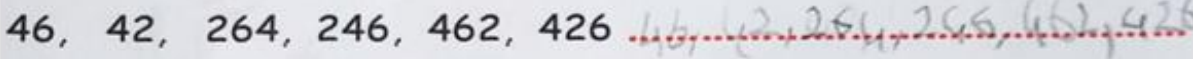

[Order the numbers below in ascending order.]

\begin{tabular}{|c|c|c|}
\hline $\begin{array}{l}\text { S.21. } 378 \text { sayısı hangi yüzlüğe } \\
\text { daha yakındır? }\end{array}$ & $\begin{array}{l}\text { S.16. } 1000 \text { sayısından önce } \\
\text { gelen sayı kaçtır? ... }\end{array}$ & $\begin{array}{l}\text { S.17. } 699 \text { sayısından sonra } \\
\text { gelen sayı kaçtır? } 0.98\end{array}$ \\
\hline
\end{tabular}

[Which busdredss is the number of 3zesleser to?] [What is the number before the number 1000?] [What is the number qfer the number 699?]

Figure 13. Incorrect Answers Value in the Category "TheA ability to Compare"

In the "operations" category, it was observed that "the ability of addition with resolved numbers" was answered correctly by 76 students, incorrectly by 9 students, and not answered by 2 students. It was the code with the highest correct answer load value in the "operations" category. In this category, it was found that the code "the ability to multiply by 10 " was answered correctly by 68 students, incorrectly by 15 students, and left unanswered by 4 students. It was determined that this code has the lowest correct answer load value in the "operations" category. Figure 14 shows the wrong answers of the students in the "operations" category.
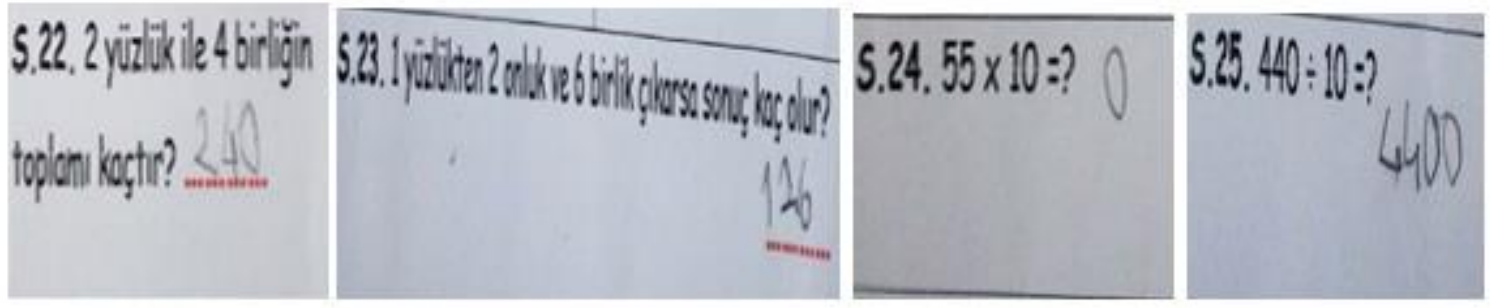

[What is the sum of 2 hundreds and 4 ones?] [Ihundreds out of 2 tens and 6 ones, how much is it?]

\section{Figure 14. Wrong Answers in the "Operations" Category \\ Results}

This paper shows that at the levels of "the ability to count objects", "the ability to group objects into ones", "the ability to group objects into tens" "the ability to group" categories created for detecting the level of 7- and 8-year-old childrens' understanding of the place value concept, it was observed that "the ability to count objects" had the highest correct response rate at both class levels, while "the ability to group objects into tens" was the code with the 
lowest correct response load value in the category "the ability to group". It was determined that the rate of correct answers at the 8-year-old level is higher than the 7-year-old in all codes. Dinç Artut and Tarım (2006) asked students to show the number 16 with counting sticks. The vast majority of students $(98.5 \%)$ were able to show the number 16 as a quantity using counting sticks. Also, $97.8 \%$ of students showed the correct number when they were asked to show only units place of 16 , and the correct answer rate was found to be $1.5 \%$ when they were asked to show the tens digit. In the study conducted with 2nd, 3rd, 4th, and 5th-grade students, it was observed that the level of answering the questions about the place value concept was low at each grade level, and the rate of answering the questions correctly increased as the grade level increased. When Kamii (1986) asked the 4th, 6th, and 8th-grade students to show the number 1 in the number $16,80 \%$ of the 8 th-grade students were able to show it through grouping 10 objects. When Kamii and Joseph (1988) looked at the correct answer percentages of 1st, 3rd, and 4th-grade students, none of the 1 st graders, $33 \%$ of the 3 rd graders, and $50 \%$ of the 4 th graders, were able to give correct answers regarding this concept. It was noted that the proportion of correct answers increases as the grade level increases. When Thompson and Bramald (2002) asked students to show what 1 in the number 16 means by using cubes, $54 \%$ of 7 -year-olds, $77 \%$ of 3rd-grade students, and $79 \%$ of 4thgrade students who participated in the study were able to answer this question correctly.

"The ability to write the number indicated by decimal base blocks", which is included in the category "the ability to express places with shapes", has the highest percentage of correct answers at both grade levels for children aged 7 and 8. "The ability to show the location of a number on a number line" was found to have the lowest correct answer rate among 7-year-old children and "the ability to show a number with decimal base blocks" had the lowest correct answer rate at the age of 8 . At the same time, it was found that the rate of answering questions correctly at the age of 8 is higher than at the age of 7 . In a study conducted by Thompson and Bramald (2002), 3 cubes were put in the block of $10 \mathrm{~s}$, and four cubes were put in the block of ones for the representation of the number 34, and it was asked what number it represents. When asked how the value of 4 cubes in the block of unity changed when transferred to a decimal block, only $10 \%$ of the students stated that this operation means multiplying the value of the number by 10 . Cayton and Brizuela (2007) showed that when first and second-grade students were asked to show the given number in base ten blocks, their success increased as their grade level increased. This is similar to our research.

Another result of the study was that "the ability to write the number using the place value", which is included in the category "the ability to position numbers", had the highest correct answer rate among 7- and 8-year-oldchildren. "The ability to place numbers in the appropriate place" was found to 
have a lower correct response rate. It was found that the rate of answering questions correctly at the age of 8 is higher than at the age of 7. Kamii and Joseph (1988) observed that students responded by taking only the number value into account, and not taking into account the place value when trying to explain the place value in the numbers. Valeras and Becker (1997) found that $96.5 \%$ of students had problems with the place value and digit value concept in their study in which primary school students' understanding of place value was tested. Kaplan (2008), in his study with seven 8th grade students, found that most of the participants thought that the concept of "digit" was related to place in the decimal number system, and the place value concept was related to a multiplication result. Participants think that there can be more than one digit in the numbers expressed in the decimal number system, and that the amount of the digits in the number changes with its position. In addition, the place value is determined by the digits that make up the number.

It was determined that 7-year-old children have an equal number of correct answer rates for "the ability to write the pronunciation of a number" and "the ability to write the number according to the pronunciation", which are in the category of the ability to rename digits. It was concluded that "the ability to write the pronunciation of a number" had a higher correct response rate than "the ability to write the number according to the pronunciation" in 8year-olds. The reason for this difference may be the existence of a problem with zero (0) in it. Many children think that zero means nothing when zero indicates a digit (Cockburn \& Litter, 2008; Olkun \& Toluk Uçar, 2012). 0 (Zero) is used as a placeholder on the basis of childrens' understanding of the place value. In number 206, "0" holds the tens digit, indicating that tens do not exist. If he/she reads the number 206, consisting of 2 hundred and 6 ones, as 26 , he/she has some misconceptions. The child then applies this understanding to the reading and writing of a number. Since the child reads the number 206 as 20 and 6 , it becomes 26 . Here, the child appears to have a very limited understanding of the place value (Cooke, 2007; Cotton, 2010; Haylock \& Cockburn, 2014). To be able to read and write numbers correctly, the child should know that the position of each digit has great importance and that the zero is used as a placeholder to show that a column is empty (Mooney et al., 2009, p. 126).

The correct answer rates of 7-year-old children in the category of "the ability to resolve" are as follows respectively; "the ability to write the number whose resolution is given", "the ability to resolve numbers", "the ability to express the number in terms of ones", and "the ability to express the number whose resolution is given in terms of ones". It was determined that the code "the ability to express the number whose resolution is given in terms of ones" is the code with the lowest correct answer load value in terms of determining the place value significance levels in the category of "the ability to resolve". The correct answer rates of 8-year-old children in the category of "the ability 
to resolve" are as follows respectively; "the ability to resolve numbers", "the ability to write the number whose resolution is given", "the ability to express the number in terms of ones", and "the ability to express the number whose resolution is given in terms of ones". The place value concept can be defined as the value that the numbers take according to their place in the number. The place value of a digit is calculated by multiplying that digit with the place value where that digit is located. For example, the number 4 in the number 3974 has the value $4 \times 1=4,7$ means $7 \times 10=70,9$ means $9 \times 100=900$, and 3 means $3 \times 1000=3000$ (Chambris, 2008). Ross (1985) found that although most students knew that 25 represented twenty-five objects, they didn't know that 2 represented 20 , and 5 represented the remaining five objects.

The correct answer rates of 7-year-old children in the category of "the ability to resolve" are as follows respectively; "the ability to write numbers before and after a number", "the ability to sort numbers", "the ability to round numbers up", and "the ability to write numbers between two numbers". In 8year-old children, the correct answer rates are as follows; "the ability to write numbers before and after a number", "the ability to sort numbers", "the ability to round numbers up", and "the ability to write numbers between two numbers". The code "the ability to write numbers between two numbers" has the lowest correct response rate at the age of 8. Paydar (2018) reached the conclusion that in the ability to compare dimension of the place value concept in natural numbers, the questions for sorting the given numbers from lower to higher were made correctly by $82.9 \%$, and determining the number between two numbers was done correctly by $67.5 \%$, and ordering the given numbers from higher to lower was done correctly by $69.2 \%$. In addition, $27.3 \%$ of the students gave incorrect answers in sorting numbers from higher to lower, $30 \%$ in determining the number between two numbers, and $15.3 \%$ in sorting numbers from lower to higher. Students achieved the desired learning level in the sub-dimension of "sorting the expression from lower to higher" in "the ability to compare" dimension, but didn't achieve the desired learning level in "the sub-dimension of sorting the expression from higher to lower" and "finding the number between two numbers".

The correct answer rates of 7-year-old children in the category of "operations" are as follows respectively; "the ability of addition with resolved numbers", "the ability of subtraction with resolved numbers", "the ability to divide by 10 ", and "the ability to multiply by 10 ". In 8 -year-old children, similarly to 7-year-olds; the correct answer rates are as follows respectively; "the ability of addition with resolved numbers", "the ability of subtraction with resolved numbers", "the ability to divide by 10 ", and "the ability to multiply by 10 ". It was found that the correct response rate was higher at the age of 8 than at the age of 7 in all codes. In a study conducted by Thompson and Bramald (2002), it was seen that only a small portion of the students who did the desired addition process correctly performed the addition by taking the 
place value into consideration. Thompson (2003) investigated information that leads to misconceptions about place value, and stated that "let's ask the question -What happens when people multiply a number by 10?-" either in primary or secondary education or high school or even teacher training institutions. The answer will become 'Add 0 to the end of the number'. When the mistakes of the students in the multiplication operation were examined, it was seen that the errors generally occurred in the multiplication with " 0 " and "1" and in the two-digit numbers and multiplication of them (Engelhardt, 1977; Cockburn \& Litter, 2008; Bamberger et al., 2010; Yorulmaz \& Önal, 2017; Önal, 2018). Rogers (2014) examined the place value concept in seven dimensions (Count, Make/Represent, Name/Record, Rename, Compare/Order, Calculate, and Estimate). Unlike other works, the level of childrens' understanding of the place value was discussed in seven dimensions in the mentioned study. These dimensions are the ability to group, the ability to express places with shapes, the ability to position numbers, the ability to rename digits, the ability to resolve, the ability to compare, and operations.

\section{Conclusion}

As a result, lower levels of 7-year-old students' understanding of the place value concept suggest that students' readiness levels are not sufficient at this age. Therefore, if understanding the place value is better for 8-year-olds, the importance of this concept in primary school programs should be discussed. In addition, it has been observed that the teaching of place value at an early age will have difficulty in making sense of this concept in the minds of students. Similarly, Thompson (2000) stated that children at an early age could not make sense of these concepts because they were incompetent in creating a mental representation. It is too late to deal with the place value concept in fifth or sixth grade (Byrge et al., 2014). Considering that the place value concept will be the basis for other mathematical information, it is considered important to provide examples of different types of questions obtained in the research. Thanks to the exercises supported by typical and nontypical examples, conceptual and operational understanding of the place value concept will be developed. In the long run, more emphasis should be given in understanding the place value concept so that students can deal with large numbers and fractional operations and create a stronger infrastructure.

\section{- Declaration of Competing Interest}

There are no relevant financial or non-financial competing interests to report. 


\section{References:}

Altun, M. (2012). Eğitim fakülteleri ve sınıf öğretmenleri için matematik öğretimi [Teaching mathematics for education faculties and classroom teachers]. Alfa İstanbul: Aktüel Yayınları.

Albayrak, M., İpek, A. S. \& Iş1k, C. (2006). Problem designing-solving studies in teaching of basic operation skills. Erzincan University Journal of Education Faculty, 8(2), 1-11.

Arslan, S., Y1ldı, C. \& Yavuz, İ. (2011). Analysis of the teaching process of place value concept]. eJournal of New World Sciences Academy Education Sciences, 6(1), 490-507.

Baltacı, A. (2018). Nitel araştırmalarda örnekleme yöntemleri ve örnek hacmi sorunsalı üzerine kavramsal bir inceleme [A conceptual review of sampling methods and sample size problems in qualitative research]. BEÜ SBE Derg.,7(1), 231-274.

Bamberger, H. J., Oberdorf, C. \& Schultz-Ferrell, K. (2010). Math misconceptions: PreK-grade 5: From misunderstanding to deep understanding. Heinemann.

Baykul, Y. (2005). İlköğretimde matematik öğretimi (1-5. sinıflar) [Teaching mathematics in primary education (grades 1-5)]. Ankara: Pegem Yayıncılık.

Boulton-Lewis, G. M. (1993). An analysis of the relation between sequence counting and knowledge of place value in the early years of school. Mathematics Education Research Journal, 5(2), 94-106, doi: https://doi.org/10.1007/BF03217189.

Brown, J. S. \& Burton, R. R. (1978). Diagnostic models for procedural bugs in basic mathematical skills. Cognitive science, 2(2), 155-192, doi: https://doi.org/10.1016/S0364-0213(78)80004-4.

Byrge, L., Smith, L. B. \& Mix, K. S. (2014). Beginnings of place value: How preschoolers write three-digit numbers. Child Development, 85(2), 437-443. doi: https://doi.org/10.1111/cdev.12162

Burns, M. (2007). About teaching mathematics: A K-8 resource (p. 536). Sausalito: Math solutions publications.

Büyüköztürk, Ş., Çakmak, E. K., Akgün, Ö. E., Karadeniz, Ş. \& Demirel, F. (2017). Bilimsel araştırma yöntemleri [Scientific research methods]. Pegem Atıf İndeksi, 1-360.

Byrge, L., Smith, L. B. \& Mix, K. S. (2014). Beginnings of place value: How preschoolers write three-digit numbers. Child Development, 85(2), 437-443. doi: https://doi.org/10.1111/cdev.12162

Cayton, G. A. \& Brizuela, B. M. (2007). First graders' strategies for numerical notation, number reading and the number concept. In Woo, J. H., Lew H. C., Park, K. S. \& Seo, D. Y. (Eds.), Proceedings of the 31st Annual Meeting of the International Group for the Psychology of Mathematics Education (vol. 2, pp. 81-88). Seoul, Korea: Seoul National University 
Chapin, S. H. \& Johnson, A. (2006). Math matters: Grades K-8 understanding the math you teach. Sausalito, CA: Math Solutions Publications.

Chambris, C. (2008). Relations entre les grandeurs et les nombres dans les mathématiques de l'école primaire. Évolution de l'enseignement au cours du 20e siècle. Connaissances des élèves actuels. Unpublished Doctoral Dissertation. Denis Diderot (PARIS University), Paris, France.

Cockburn, A. D. (2005). Teaching mathematics with insight: the identification, diagnosis and remediation of young children's mathematical errors. Routledge.

Cockburn, A. D. \& Littler, G. (Eds.) (2008). Mathematical misconceptions: A guide for primary teachers. Sage.

Cooke, H. (2007). Mathematics for primary and early years: Developing subject knowledge. SAGE.

Cotton, T. (2010). Understanding and teaching primary mathematics. Pearson Education Limited. Harlow: England.

Creswell, J. W. (2016). Research desig.: qualitative, quantitative, mixed methods approaches. University of Nebraska-Lincoln.

Cuffel, T. A. (2009). Linking place value concepts with computational practices in third grade. Unpublished Master's Thesis, University of Central Florida, Florida.

Dinç-Artut, P. \& Tarım, K. (2006). Elementary students' comprehension of place value concept. Journal of Theory and Practice in Education, 2(1), 26-36. Engelhardt, J. M. (1977). Analysis of children's computational errors: A qualitative approach. British Journal of Educational Psychology, 47(2), 149154, doi. https://doi.org/10.1111/j.2044-8279.1977.tb02340.x.

Fuson, K. C. (1990). Conceptual structures for multiunit numbers: Implications for learning and teaching multidigit addition, subtraction, and place value. Cognition and Instruction, 7(4), 343-403.

Fuson, K. C. \& Briars, D. J. (1990). Using a base-ten blocks learning/teaching approach for first-and second-grade place-value and multidigit addition and subtraction. Journal for Research in Mathematics Education, 21(3), 180-206, doi: https://doi.org/10.2307/749373.

Gibbs, G. R. (2007). Thematic coding and categorizing, analyzing qualitative data. SAGE Publications Ltd., London.

Glesne, C. (2012). Nitel araştırmaya giriş [Introduction to qualitative research] (A. Ersoy and P. Yalçınoğlu, Trans.). Ankara: Anı Yayıncılık.(Original work published 1992).

Hansen, A. (2014). Children's errors in mathematics, Los Angeles: Learning Matters.

Haylock, D. \& Cockburn, A. (2014). Küçük çocuklar için matematiği anlama [Understanding math for young children]. (Z. Yılmaz, Çev.). Nobel Akademik, Ankara 
Jones, G., Thornton, C., Putt, I., Hill, K., Mogill, T., Rich, B. \& Van Zoest, L. (1996). Multidigit number sense: a framework for instruction and assessment. Journal for Research in Mathematics Education, 27(3), 310-336, doi: https://doi.org/10.2307/749367.

Kamii, C. (1986). Place value: An explanation of its difficulty and educational implications for the primary grades. Journal of Research in Childhood Education, 1(2), 75-86, doi: https://doi.org/10.1080/02568548609594909.

Kamii, C. \& Joseph, L. (1988). Teaching place value and double-column addition. Arithmetic teacher, 35(6), 48-52, doi: https://10.5951/AT.35.6.0048. Kaplan, H. A. (2008). İlköğretim sekizinci sınıf öğrencilerinin ' 'basamak' ve ' 'basamak değeri' kavramları ile ilgili zihinsel yapılarının incelenmesi [An examination of $8^{\text {th }}$ grade students" construction about "place" and "place value" concepts]. Unpublished Master's Thesis, Gazi Üniversity, Ankara.

Major, K. (2012). The development of an assessment tool: Student knowledge of the place value concept. In J. Dindyal, L. P. \& Cheng, S. F. Ng (Eds.). Mathematics education: Expanding horizons (Proceedings of the 35 th annual conference of the Mathematics Education Research Group of Australasia). Singapore: MERGA

McMillan, J. H. (2000). Educational research: Fundamentals for the consumer. New York: Longman.

Merriam, S. B. \& Tisdell, E. J. (2015). Qualitative research: A guide to design and implementation. John Wiley \& Sons.

Mooney, C., Briggs, M., Fletcher, M., Hansen, A. \& McCulloch, J. (2009).

Primary mathematics: Teaching theory and practice (4th ed.). Exeter, UK:

Learning Matters Ltd.

Mutlu, Y., \& Sarı, M. H. (2019). Developing the understanding of place-value in primary students. Kastamonu Education Journal, 27(2), 657-667. doi: https://10.24106/kefdergi.264

Nataraj, M. S. \& Thomas, M. O. (2007). Developing the place value concept. Mathematics: Essential Research, Essential Practice, 2, 523-532.

Olkun, S. \& Toluk-Uçar, Z. (2012). İlköğretimde etkinlik temelli matematik ögretimi [Activity-based mathematics teaching in primary education]. Ankara: Anı Yayınc1lik

Önal, H. (2018). İlkokul 1. ve 2. sınıf öğrencilerinin matematik dersinde dört işlem ile ilgili yaptıkları hatalar ve çözüm önerileri [Mistakes made by first and second grade primary school students in mathematics lesson about four operations and their solution suggestions]. Unpublished Doctoral Dissertation, Marmara Üniversity, İstanbul.

Paydar, S. (2018). 4.sınıf öğrencilerinin basamak değerini anlama düzeylerinin incelenmesi [Investigation of 4th grade students' level of understanding place value]. Unpublished Master's Thesis, Gazi Üniversity, Ankara 
Rogers, A. N. (2014). Investigating whole number place value assessment in Years 3-6: Creating an evidence-based Developmental Progression. Unpublished Doctoral Dissertation. RMIT University, Melbourne, Australia.

Ross, S. H. (1986-April). The development of children's place-value numeration concepts in grades two through five. The Annual Meeting of the American Educational Research Association (67th), San Francisco, CA.

Sharma, M. C. (1993). Place value concept: How children learn it and how to teach it. Math Notebook, 10(1-2), 1-26.

Tarım, K., \& Dinç-Artut, P. (2013). Preservice teachers' levels of understanding of place value and numeration systems. Elementary Education Online, 12(3), 759-769.

Thompson, I. (2000). Teaching place value in the UK: time for reappraisal? Educational Review, 52(3), 291-298, doi: https://doi.org/10.1080/713664046. Thompson, I. \& Bramald, R. (2002). An investigation of the relationship between young children's understanding of the place value concept and their competence at mental addition (Report for the Nuffield Foundation). Newcastle upon Tyne: University of Newcastle upon Tyne.

Tosun, M. (2011). İlköğretim öğrencilerinin basamak değer kavramına ilişkin becerilerinin incelenmesi [The investigation of primary school students' skill in place value]. Unpublished Master's Thesis, Çukurova Üniversity, Adana.

Valeras, M. \& Becker, J. (1997). Children's developing understanding of place value: semiotic aspects. Cognition and Instruction, 15(2), 265-286. doi: https://10.1207/s1532690xci1502_4

Van De Walle, J. A., Karp, K. S. \& Bay-Williams, J. W. (2014). İlkokul ve ortaokul matematiği gelişimsel yaklaşımla öğretim[Teaching primary and secondary school mathematics with a developmental approach] (7. Baskı). Çev. S. Durmuş. Ankara: Nobel Yayınları.

Yorulmaz, A. \& Önal, H. (2017). Examination of the Views of Class Teachers Regarding the Errors Primary School Students Make in Four Operations. Universal Journal of Educational Research, 5(11), 1885-1895, doi https://10.13189/ujer.2017.051105. 